\title{
IN VITRO CONSERVATION AND LEAF ANATOMY OF DIFFERENT CHEMOTYPES OF Lippia alba (Mill.) N. E. BR
}

\author{
CONSERVAÇÃO IN VITRO E ANATOMIA FOLIAR DE DIFERENTES \\ QUIMIOTIPIOS DE Lippia alba (Mill.) N. E. BR
}

\section{Magna Galvão PEIXOTO' ${ }^{1}$; Ana Catarina Lima de OLIVEIRA ${ }^{2}$; Arie Fitzgerald BLANK ${ }^{3}$; Jefferson Henrique Santos SILVA ${ }^{4}$; José Magno Queiroz LUZ ${ }^{5}$; Maria de Fátima ARRIGONI-BLANK}

1. Professor, Doutor, Universidade Federal do Sergipe - UFS, Campus Lagarto, Lagarto, SE, Brasil; 2. Professor, Doutor, IFS, Nossa Senhora da Glória, SE, Brasil; 3. Professor, Doutor, Departamento de Engenharia Agronômica - UFS, São Cristóvão, SE, Brasil; 4. Graduado em Agronomia - UFS, São Cristóvão, SE, Brasil; 5. Professor, Doutor, Instituto de Ciências Agrárias - UFU, Uberlândia, MG, Brasil; 6. Professor, Doutor, Departamento de Engenharia Agronômica - UFS, São Cristóvão, SE, Brasil. arrigoni@ufs.br

\begin{abstract}
The aim of this work was to develop an in vitro conservation protocol for Lippia alba that involved mineral oil and to study the leaf anatomy of $L$. alba genotypes in in vitro and ex vitro environments. In vitro conservation involved five genotypes; LA-13 and LA-57 (carvone chemotype); LA-22 (linalool chemotype); and LA-29 and LA-44 (citral chemotype). Each genotype was treated with mineral oil, with water, and a control at $18^{\circ} \mathrm{C}$ and $23^{\circ} \mathrm{C}$. Survival (\%), shoot height $(\mathrm{cm})$ and leaf color were assessed at 180 and 270 days. The genotypes with the best in vitro conservation outcomes (LA-13 and LA-57) were used to study the anatomy of the leaves. Midrib thickness, leaf blade thickness, adaxial and abaxial cuticles and the number of glandular and tector trichomes were assessed. A temperature of $18^{\circ} \mathrm{C}$ was optimal for the conservation of genotypes of the carvone chemotypes. The explants were short and had green leaves. This was especially true for LA-57, whose height did not exceed $2.0 \mathrm{~cm}$. At 270 days, the LA-13 and LA-57 genotypes continued to have green and viable leaves, especially LA-57, which had the lowest mean height. Field plants of the carvone chemotype had thicker midribs, leaf blades, and cuticles and had more trichomes. The LA-57 genotype had the most glandular and tector trichomes.
\end{abstract}

KEYWORDS: Verbenaceae. Slow Growth. Plant anatomy. Morphology.

\section{INTRODUCTION}

Lippia alba (Mill.) N.E.Br. is a native South American plant that is used widely for medicinal purposes. The high chemical variability of its essential oils supports differentiation of the plants into several chemotypes and makes this species the object of studies that involve its antibacterial, antifungal and antiviral properties (GUPTA et al., 2001; HENNEBELLE et al., 2008). Such chemical diversity results from environmental factors and from the genotypic variation of these plants (TAVARES et al., 2005) and accounts for the growing interest in its conservation.

With the increased genetic erosion, it is necessary to prioritize studies regarding the conservation of germplasm of this species. In vitro conservation is one of the methods that can be used for germplasm conservation and involves maintaining the plants under specific protocols of decreased temperature and decreased light intensity and varying culture media that result in slow growth (SOUZA et al., 2009). The maintenance of genotypes under aseptic conditions, reduction of labor costs, optimization of the use of physical space, and ease of exchange of plant material are some of the advantages of in vitro conservation (ENGELMANN, 2011).

The immersion of plant tissues in mineral oil, a method that was originally reported by Caplin (1959) and is still underutilized, is one of the many existing protocols for in vitro conservation. This method is important because it is inexpensive and does not require sophisticated equipment (SHARMA et al., 2012). There is no published study on the use of this method for in vitro conservation of L. alba.

The effectiveness of such conservation protocols requires a successful transition from an in vitro to an ex vitro environment. Knowledge of the anatomy of a species therefore becomes important because the vegetative organs of plants that are grown in vitro have poorly differentiated tissues and structures compared with plants that are grown in a greenhouse (Apóstolo et al. 2005; Dousseau et al. 2008). Knowledge of the leaf anatomy of medicinal plants is valuable for the correct identification of the species that are studied and is essential for the management and conservation of native medicinal species and for understanding relationships between these species and the environment (NASCIMENTO-SILVA; PAIVA 2007). 
This study aimed to develop an in vitro conservation protocol for $L$. alba that used mineral oil and to analyze the leaf anatomy of its genotypes in vitro and ex vitro environments.

\section{MATERIAL AND METHODS}

\section{Plant material and local}

Five $L$. alba genotypes that belong to three chemotypes were used in this study: LA-13 and LA57 (carvone chemotype), LA-22 (linalool chemotype), and LA-29 and LA-44 (citral chemotype). All of the plant material originated from the Active Germplasm Bank of the Federal University of Sergipe, which is located on the Research Farm "Campus Rural da UFS", in the municipality of São Cristóvão, Sergipe State, Brazil, $11^{\circ} 00^{\prime} \mathrm{S}$ latitude and $37^{\circ} 12^{\prime} \mathrm{W}$ longitude. The experiments were conducted in the Laboratory of Tissue Culture and Plant Breeding of the Department of Agronomic Engineering, Federal University of Sergipe, Brazil.

\section{Seedling production and in vitro establishment}

To obtain the explants, seedlings were produced by cutting and were planted in 8-liter pots with sand, soil and composted cattle manure (2:1:1 $\mathrm{v} / \mathrm{v} / \mathrm{v})$ as the substrate. The seedlings were maintained in an agricultural greenhouse that had $50 \%$ black shade cloth, irrigation and intermittent misting. Nodal segments of these seedlings that had been disinfected were used as explants for in vitro establishment. To establish the plants, the plant material was immersed in running water $(30 \mathrm{~min})$, followed by an initial immersion in $70 \%$ ethanol $(\mathrm{v} / \mathrm{v} ; 30 \mathrm{sec})$ and a subsequent immersion in $1 \%$ mercuric chloride solution that was stirred $(8 \mathrm{~min})$. The nodal segments were then rinsed in distilled and autoclaved water. The explants were inoculated into test tubes that had $15 \mathrm{ml}$ of MS (MURASHIGE; SKOOG, 1962) culture medium (Sigma-Aldrich, Sao Paulo, Brazil), that was supplemented with 0.7 g. $\mathrm{L}^{-1}$ agar and 30 g. $\mathrm{L}^{-1}$ sucrose, had a $\mathrm{pH}$ of 5.8 and had been autoclave-sterilized $\left(121 \pm 1^{\circ} \mathrm{C}\right.$ and 1.05 atm for $15 \mathrm{~min})$. After the inoculation of the explants, the test tubes were transferred to a growth room that had a controlled temperature of $25 \pm 2{ }^{\circ} \mathrm{C}$ and were exposed to $60 \mu \mathrm{mol} . \mathrm{m}^{-2} \cdot \mathrm{s}^{-1}$ light intensity with a 12-12 photoperiod.

\section{In vitro conservation}

Nodal segments that were approximately 2.0 $\mathrm{cm}$ tall and had originated from plants that had already been established in vitro and were 60 days old were used as explants. The explants were inoculated into test tubes $(16 \times 150 \mathrm{~mm})$ with $15 \mathrm{ml}$ of MS culture medium (MURASHIGE; SKOOG, 1962) that was supplemented with 0.7 g. $\mathrm{L}^{-1}$ agar and 30 g. $L^{-1}$ sucrose. There were three experimental treatments. The first involved supplementation with $3.0 \mathrm{ml}$ per test tube of mineral oil that had been autoclaved previously and cooled to $25^{\circ} \mathrm{C}$. The mineral oil was placed in the tubes with a micropipette until it completely covered the explant. The second treatment involved supplementation with $3.0 \mathrm{ml}$ of distilled water per test tube, until the water completely covered the explant. The third treatment was a control that involved unsupplemented culture medium only.

The experimental design was completely randomized in a $5 \times 3 \times 2$ factorial arrangement, with six replicates. Each replicate consisted of five test tubes that each contained a nodal segment. There were five genotypes (LA-13, LA-22, LA-29, LA-44 and LA-57), three treatments (with mineral oil, with water and without mineral oil [control]), and two temperatures $\left(18^{\circ} \mathrm{C}\right.$ and $\left.23^{\circ} \mathrm{C}\right)$. The material was maintained in a biochemical oxygen demand (BOD) chamber at the respective temperatures with a 12-12 photoperiod. The evaluated parameters were: survival (\%), shoot height (on a rating scale on which $1=$ less than or equal to $2.0 \mathrm{~cm}, 2=2.1$ to $4.0 \mathrm{~cm}, 3=4.1$ to $6.0 \mathrm{~cm}$, $4=6.1$ to $8.0 \mathrm{~cm}, 5=8.1$ to $10.0 \mathrm{~cm}$ and $6=$ equal to or greater than $10.1 \mathrm{~cm}$ ) and leaf color (on a rating scale that was adapted from Lemos et al. (2002) on which 1 = green leaves, $2=$ pale-green leaves, $3=$ onset of leaf drying, $4=$ between $30 \%$ and $50 \%$ dead leaves, $5=$ more than $50 \%$ dead leaves and $6=$ completely dead). Measurements were made at 180 and at 270 days.

\section{Leaf anatomy}

The genotypes with the best outcomes from in vitro conservation with mineral oil were selected for the experiment that compared the leaf anatomy of the in vitro plants and acclimated and field plants that had originated from the Active Germplasm Bank of the Federal University of Sergipe. They plants were acclimated and maintained in a protected environment that had 50\% black shade cloth and intermittent misting that ensured high humidity. Leaf anatomy was assessed by means of samples that were collected in the middle region of the third fully expanded leaf of plants that had been grown under the three test conditions. The samples were subsequently fixed and preserved in $70 \%$ ethanol. Cross sections of the middle region of the leaves were sterilized with sodium hypochlorite ( $1 \%$ 
active chlorine) that was followed by triple rinsing in distilled water.

The material was then stained with safrablau (safranin solution [1\%] and astra blue solution [1\%] at a proportion of 7:3) and mounted on semipermanent slides with glycerol water and a cover slip. The experimental design was completely randomized and consisted of 15 replicates of cross sections of each genotype and three growth conditions (in vitro, acclimated and field). The photomicrographs were taken with an optical microscope that was equipped with a Leica DM500 camera (Leica Microsystems Inc., Buffalo Grove, Illinois, U.S.A.) and were displayed on a computer screen by means of LAS EZ software (Leica Microsystems Inc.). The parameters that were measured were midrib thickness $(\mu \mathrm{m})$, leaf blade thickness $(\mu \mathrm{m})$, adaxial and abaxial cuticles $(\mu \mathrm{m})$ and the number of glandular and tector trichomes $/ \mathrm{mm}^{2}$. All anatomical measurements were performed using ImageTool image analysis software (University of Texas Health Science Center, San Antonio, U.S.A.). The images were calibrated with a microscope ruler that was photographed at the same magnification as the photomicrographs.

\section{Statistical analysis}

The in vitro conservation and leaf anatomy results were subjected to Analysis of variance using Sisvar $^{\circledR}$ software (http://www.dex.ufla.br/ danielff/softwares.htm) (FERREIRA, 2011). Means, when significant, were clustered using Tukey's test at a 5\% level of significance.

\section{RESULTS}

\section{In vitro conservation at 180 days}

The $18^{\circ} \mathrm{C}$ temperature was effective in conserving the five $L$. alba genotypes as measured by the survival, color and height of the explants. The $23^{\circ} \mathrm{C}$ temperature was unsuitable for explant survival, with mean values below $24 \%$ for all three parameters and no significant differences between the mineral oil treatment and the water and control treatments (Table 1). Explants that were immersed in mineral oil and maintained at $18^{\circ} \mathrm{C}$ had a survival rate that was greater than $86 \%$ at 180 days, and there were no significant differences in survival among the genotypes.

The survival rates of the water-immersed and control explants were lower than that of explants that were immersed in mineral oil, except for the LA-57 genotype, which had means greater than $83 \%$ under all three treatments (Table 1). In terms of leaf color at $18^{\circ} \mathrm{C}$, the treatment with mineral oil differed from the control treatment and from the water-immersion treatment. LA-13 and LA-57, which both belong to the carvone chemotype, stood out among the genotypes that were immersed in mineral oil by having means that corresponded to the green leaves category (1.2 and 1.1 , respectively). The other genotypes had means that corresponded to the 30 -to-50\% dead leaves category.

Table 1. Survival (\%) of Lippia alba genotypes at 180 days at different temperatures and with treatments.

\begin{tabular}{|c|c|c|c|c|c|}
\hline \multirow[b]{2}{*}{ Treatments } & \multicolumn{5}{|c|}{ Genotypes } \\
\hline & $L A-13$ & $L A-22$ & $L A-29$ & $L A-44$ & $L A-57$ \\
\hline \multirow{4}{*}{$\begin{array}{l}\text { With mineral oil } \\
\text { With water } \\
\text { Control }\end{array}$} & & & ${ }^{5} \mathrm{C}$------ & & \multirow{4}{*}{$\begin{array}{l}100.0^{\mathrm{aA} \alpha} \\
86.7^{\mathrm{aA} \alpha} \\
83.3^{\mathrm{aA} \alpha}\end{array}$} \\
\hline & $100.0^{\mathrm{aA \alpha} \alpha}$ & $93.3^{\mathrm{aA} \alpha}$ & $86.7^{\mathrm{aA} \alpha}$ & $86.7^{\mathrm{aA} \alpha}$ & \\
\hline & $50.0^{\mathrm{bB} \alpha}$ & $40.0^{\mathrm{bB} \beta}$ & $50.0^{\mathrm{bB} \alpha}$ & $20.0^{\mathrm{bB} \alpha}$ & \\
\hline & $46.7^{\mathrm{bBC} \alpha}$ & $36.7^{\mathrm{bBC} \beta}$ & $56.7^{\mathrm{bAB} \alpha}$ & $23.0^{\mathrm{bC} \alpha}$ & \\
\hline \multirow{4}{*}{$\begin{array}{l}\text { With mineral oil } \\
\text { With water } \\
\text { Control }\end{array}$} & & --4- & ${ }^{\circ} \mathrm{C}$ & ----- & \multirow{4}{*}{ 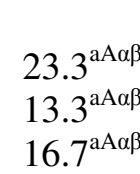 } \\
\hline & $16.7^{\mathrm{aA} \beta}$ & $13.3^{\mathrm{aA} \alpha}$ & $20.0^{\mathrm{aA} \beta}$ & $3.3^{\mathrm{aA} \beta}$ & \\
\hline & $10.0^{\mathrm{aA} \beta}$ & $13.3^{\mathrm{aA} \alpha}$ & $6.7^{\mathrm{aA} \beta}$ & $6.7^{\mathrm{aA} \beta}$ & \\
\hline & $6.7^{\mathrm{aA} \beta}$ & $10.0^{\mathrm{aA} \alpha}$ & $13.3^{\mathrm{aA} \beta}$ & $10.0^{\mathrm{aA} \beta}$ & \\
\hline CV (\%) & \multicolumn{5}{|c|}{50.00} \\
\hline
\end{tabular}

All of the treatments were in categories of more than $50 \%$ dead leaves at $23^{\circ} \mathrm{C}$, and there were no differences among genotypes (Table 2). All genotypes, with the exception of LA-22, that were treated with mineral oil at $18^{\circ} \mathrm{C}$ had mean plant heights that were lower than 3.0, which corresponds to growth ranging from 2.1 to $4.0 \mathrm{~cm}$ (Table 3). However, as is shown in Table 2, the LA-29 and 
LA-44 genotypes, which both belong to the citral chemotype, had means for the color parameter that were greater than 4.5 , which corresponds to the category of 30 to $50 \%$ dead leaves, which is undesirable for in vitro conservation. The genotype LA-22 (linalool chemotype) grew taller than 10.0 $\mathrm{cm}$, and LA-13, LA-29, LA-44 and LA-57 were the shortest, as mentioned above.

The $23^{\circ} \mathrm{C}$ temperature accelerated explant growth in all three treatments, except for the LA-29 and LA-44 genotypes, which showed high mean values of the color parameter but low mean heights in the mineral oil treatment. Thus, for 180 days of conservation at $18^{\circ} \mathrm{C}$, the mineral oil treatment of genotypes LA-13 and LA-57 (carvone chemotype) had the best results in terms of the three parameters that were analyzed. There was $100 \%$ survival of these two genotypes, their color means, which were 1.2 for LA-13 and 1.1 for LA-57, corresponded to green leaves, and they grew to approximately 4.0 $\mathrm{cm}$ in height.

Table 2. Color (scores 1 to 6)* of Lippia alba genotypes at 180 days at different temperatures and with different treatments.

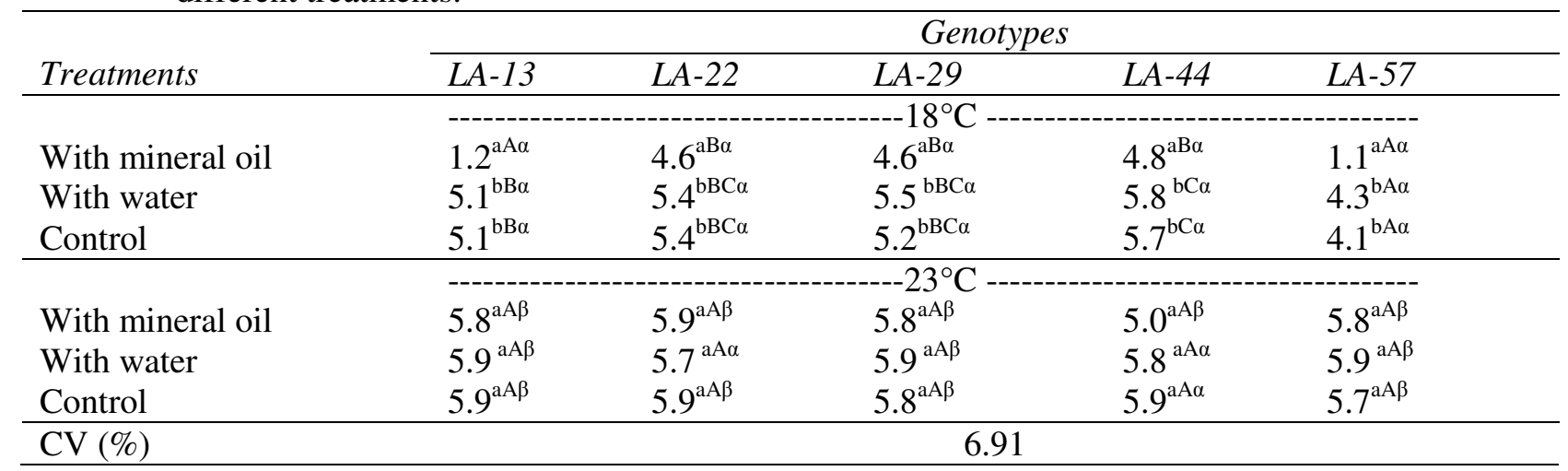

Means that are followed by the same lower case letters in columns of the same temperature, upper case letters in rows, and Greek letters between temperatures in columns and the same treatments with mineral oil, showed no significant differences according to Tukey's test $(\mathrm{p}>0.05 \%)$; *Rating scale: 1 = green leaves; $2=$ pale-green leaves; $3=$ onset of leaf drying; $4=$ from $30 \%$ to $50 \%$ dead leaves; $5=$ more than $50 \%$ dead leaves; $6=$ completely dead.

Table 3. Height (score 1 to 6 )* of Lippia alba genotypes at 180 days at different temperatures and with different treatments.

\begin{tabular}{|c|c|c|c|c|c|}
\hline \multirow[b]{2}{*}{ Treatments } & \multicolumn{5}{|c|}{ Genotypes } \\
\hline & $L A-13$ & $L A-22$ & $L A-29$ & $L A-44$ & $L A-57$ \\
\hline & \multicolumn{5}{|c|}{ 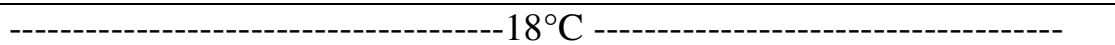 } \\
\hline With mineral oil & $2.3^{\mathrm{aC} \alpha}$ & $6.0^{\mathrm{aD} \alpha}$ & $1.2^{\mathrm{aB} \beta}$ & $1.1^{\mathrm{aA} \alpha}$ & $1.2^{\mathrm{aAB} \alpha}$ \\
\hline With water & $6.0^{\mathrm{bA \alpha}}$ & $6.0^{\mathrm{aA} \alpha}$ & $6.0^{\mathrm{bA \alpha}}$ & $6.0^{\mathrm{bA \alpha}}$ & $6.0^{\mathrm{bA \alpha}}$ \\
\hline Control & $6.0^{\mathrm{bA} \alpha}$ & $6.0^{\mathrm{aA} \alpha}$ & $6.0^{\mathrm{bA \alpha}}$ & $6.0^{\mathrm{bA} \alpha}$ & $6.0^{\mathrm{bA \alpha}}$ \\
\hline With mineral oil & $6.0^{\mathrm{aB} \beta}$ & $6.0^{\mathrm{aB} \alpha}$ & $\begin{array}{r}23^{\circ} \mathrm{C}- \\
1.0^{\mathrm{aA} \alpha}\end{array}$ & $1.0^{\mathrm{aA} \alpha}$ & $6.0^{\mathrm{aB} \beta}$ \\
\hline With water & $6.0^{\mathrm{aA} \alpha}$ & $6.0^{\mathrm{aA} \alpha}$ & $6.0^{\mathrm{bA \alpha}}$ & $6.0^{\mathrm{bA \alpha}}$ & $6.0^{\mathrm{aA} \alpha}$ \\
\hline Control & $6.0^{\mathrm{aA} \alpha}$ & $6.0^{\mathrm{aA} \alpha}$ & $6.0^{\mathrm{bA \alpha}}$ & $6.0^{\mathrm{bA \alpha} \alpha}$ & $6.0^{\mathrm{aA} \alpha}$ \\
\hline $\mathrm{CV}(\%)$ & \multicolumn{5}{|c|}{1.46} \\
\hline
\end{tabular}

Means that are followed by the same lower case letters in columns of the same temperature, upper case letters in rows, and Greek letters between temperatures in columns and the same treatments with mineral oil showed no significant differences according to Tukey's test $(\mathrm{p}>0.05 \%)$.

\section{In vitro conservation at 270 days}

For 270 days of conservation at $18^{\circ} \mathrm{C}$, the LA-13 and LA-57 genotypes that were immersed in mineral oil showed mean survival rates that were greater than $96 \%$, and there was no significant difference between them in survival (Table 4). Both genotypes had color means that corresponded to green and viable leaves (Figure 1A and 1B).
The two genotypes did differ significantly in height. LA-57 had a height category mean of 2.5 , which corresponds to a height of 2.1 to $4.0 \mathrm{~cm}$, and LA-13 had height category mean of 4.3 , which corresponds to a height of 6.1 to $8.0 \mathrm{~cm}$ (Table 4). The waterimmersion and control treatments resulted in low survival rates but high values for color and height (Table 4). At 270 days of conservation, both the LA-13 and LA-57 genotypes resumed their growth 
when placed under normal conditions of in vitro multiplication, which is critical for the success of the method because the plants must have sufficient

Table 4. Survival (\%), color and height of Lippia alba genotypes at 270 days at $18^{\circ} \mathrm{C}$.

\begin{tabular}{|c|c|c|}
\hline \multirow{2}{*}{ Treatments } & \multicolumn{2}{|c|}{ Genotypes } \\
\hline & $L A-13$ & $L A-57$ \\
\hline & \multicolumn{2}{|c|}{ 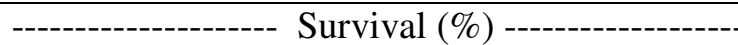 } \\
\hline With mineral oil & $96.7^{\mathrm{aA}}$ & $100.0^{\mathrm{aA}}$ \\
\hline With water & $10.0^{\mathrm{aB}}$ & $3.3^{\mathrm{aB}}$ \\
\hline Control & $10.0^{\mathrm{aB}}$ & $0.0^{\mathrm{aB}}$ \\
\hline $\mathrm{CV}(\%)$ & \multirow{2}{*}{\multicolumn{2}{|c|}{35.44}} \\
\hline & & - \\
\hline With mineral oil & $1.9^{\mathrm{bA}}$ & $1.4^{\mathrm{aA}}$ \\
\hline With water & $5.9^{\mathrm{aB}}$ & $5.9^{\mathrm{aB}}$ \\
\hline Control & $5.9^{\mathrm{aB}}$ & $6.0^{\mathrm{aB}}$ \\
\hline $\mathrm{CV}(\%)$ & \multicolumn{2}{|c|}{5.88} \\
\hline & \multicolumn{2}{|c|}{---------- Height (score 1 to 6$)^{* *}$} \\
\hline With mineral oil & $4.3^{\mathrm{bA}}$ & $2.5^{\mathrm{aA}}$ \\
\hline With water & $6.0^{\mathrm{aB}}$ & $6.0^{\mathrm{aB}}$ \\
\hline Control & $6.0^{\mathrm{aB}}$ & $6.0^{\mathrm{aB}}$ \\
\hline $\mathrm{CV}(\%)$ & \multicolumn{2}{|c|}{7.94} \\
\hline
\end{tabular}

Means that are followed by the same lower case letters in rows (between genotypes) and upper case letters in columns (between treatments with mineral oil), showed no significant differences according to Tukey's test ( $\mathrm{p}>0.05 \%)$; *Rating scale: $1=$ green leaves; 2 $=$ pale-green leaves; $3=$ early leaf drying; $4=$ from 30 to $50 \%$ dead leaves; $5=$ more than $50 \%$ dead leaves; $6=$ completely dead; $* *$ Rating scale: $1=$ less than or equal to $2.0 \mathrm{~cm}, 2=2.1$ to $4.0 \mathrm{~cm}, 3=4.1$ to $6.0 \mathrm{~cm}, 4=6.1$ to $8.0 \mathrm{~cm}, 5=8.1$ to $10.0 \mathrm{~cm}$ and $6=$ equal to or greater than $10.1 \mathrm{~cm}$.

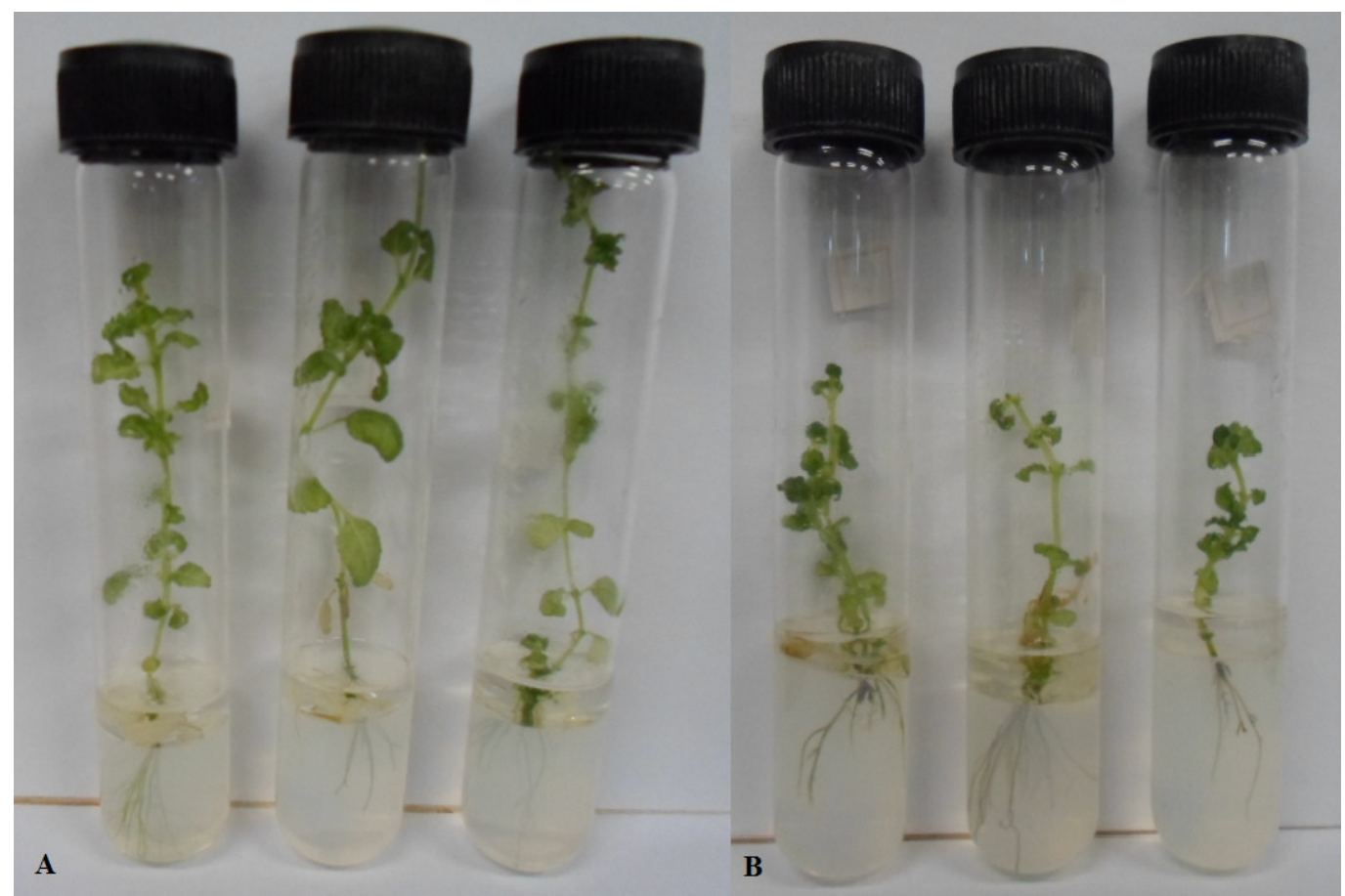

Figure 1. Lippia alba plants of the carvone chemotype that were immersed in mineral oil for 270 days, LA13(A) and LA-57 (B). 


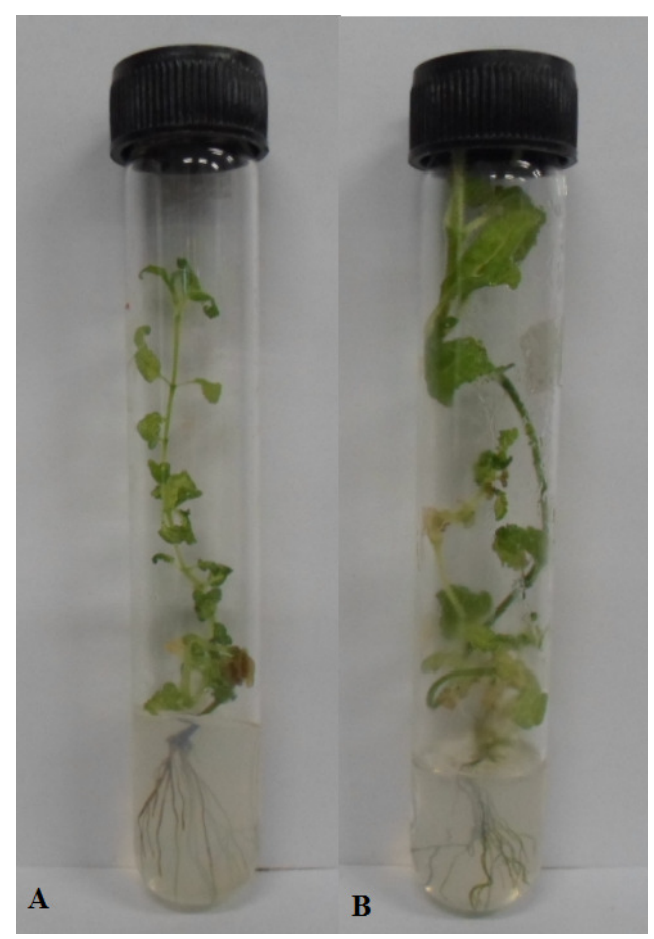

Figure 2. The resumption of plant growth of Lippia alba (carvone chemotype) after 40 days of immersion in mineral oil, LA-13(A) and LA-57(B).

Both LA-13 and LA-57 were viable as measured by the parameters that represent survival, color and leaf size. LA-57 had the lowest height values in the mineral oil treatment (Table 4). Thus, conservation by immersion in mineral oil after the

\section{Leaf anatomy of the LA-13 and LA-57 genotypes}

The mesophyll of $L$. alba is characterized by palisade parenchyma (pp) that is in contact with the adaxial side (ads) and by spongy parenchyma (sp) on the abaxial side (abs; Figure 3). There was a significant difference in midrib (mr) thickness between environments. As hypothesized, plants that had already been established in field conditions had thicker midribs than acclimated plants. Among the field plants, the LA-13 genotype had significantly thicker midribs than the LA-57 genotype (Table 5). Acclimated and field plants had thicker leaf blades than plants that were maintained in vitro. LA-13 had the thickest leaf blades (Table 5). There was a significant difference in the number of glandular trichomes among environments for both genotypes. The leaves of field plants, especially those of the LA-57 genotype, had more trichomes. LA-57 had 8.6 glandular trichomes per $\mathrm{mm}^{-2}$ (Table 5). There were no significant differences in the number of tector trichomes among the in vitro, acclimated and field environments for the LA-13 genotype, and there was no significant difference between the in 270-day period was more effective for the carvone chemotype (LA-13 and LA-57). Because of the promising results with LA-13 and LA-57 when they were immersed in mineral oil, these two genotypes were selected for the examination of leaf anatomy. vitro and field environments for the LA-57 genotype (Table 5). Both genotypes had thicker cuticles on the adaxial side under field conditions. There was no significant difference between acclimated and field conditions in the cuticle thickness on the adaxial side of leaves of plants of the LA-57 genotype (Table 6). The leaf cuticle could not be measured for the plants that were grown in vitro. 


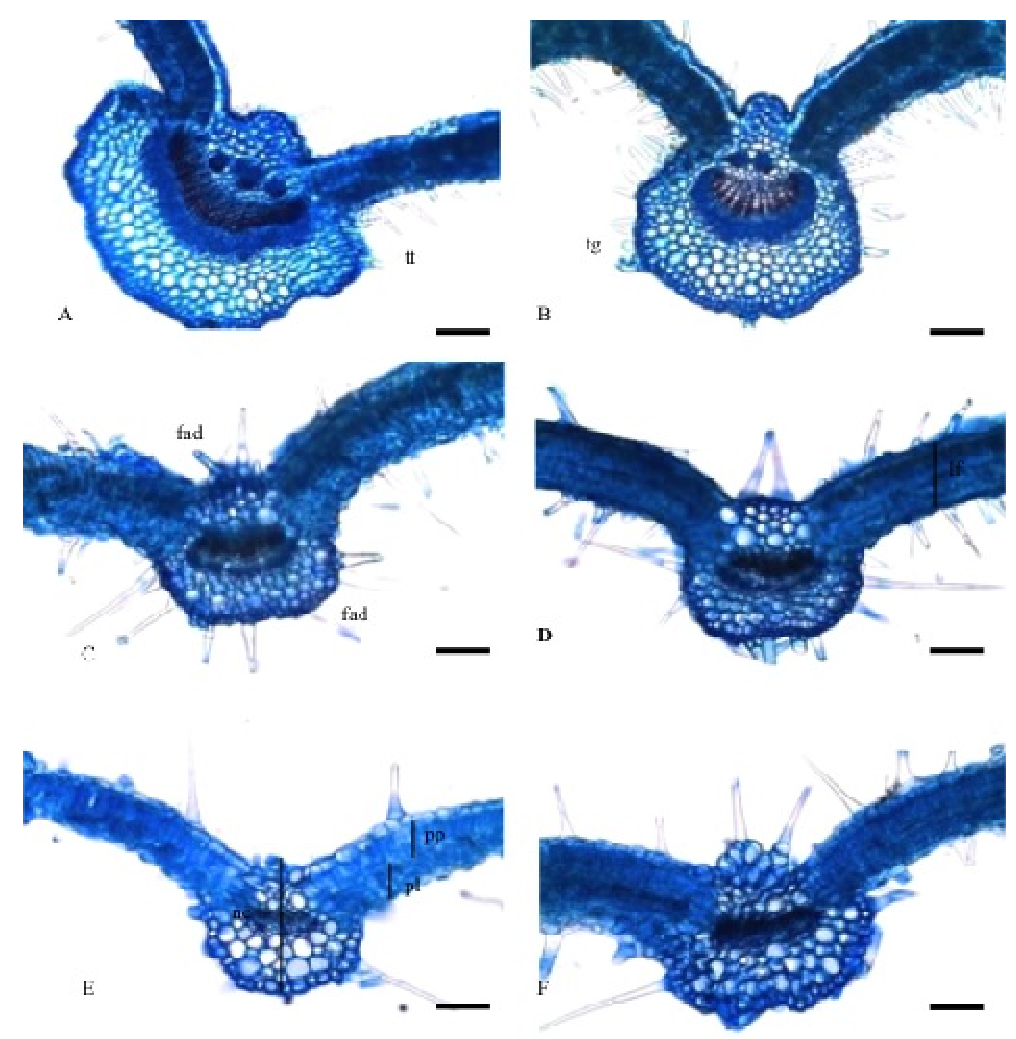

Figure 3. Photomicrographs of cross sections of the leaf structure of the carvone phenotype of Lippia alba, that originated from the field: LA-13(A) and LA-57(B); had been acclimated: LA-13(C) and LA-57( D); or grown in vitro: LA-13(E) and LA-57(F); lb: leaf blade; mr: midrib; tt: tector trichome; gt: glandular trichome; pp: palisade parenchyma; sp: spongy parenchyma; ads: adaxial side; abs: abaxial side. Scale bars: $50 \mu \mathrm{m}$.

Table 5. Midrib thickness (mr), leaf blade thickness (lb), the number of glandular trichomes (gt) and the number of tector trichomes (tt) of the LA-13 and LA-57 genotypes of Lippia alba, in three environments.

\begin{tabular}{|c|c|c|c|c|c|c|c|c|}
\hline \multirow{2}{*}{$\begin{array}{c}\text { Environment } \\
s\end{array}$} & \multicolumn{2}{|c|}{$m r(\mu m)$} & \multicolumn{2}{|c|}{$l b(\mu m)$} & \multicolumn{2}{|c|}{ gt per $m^{-2}$} & \multicolumn{2}{|c|}{ tt per $\mathrm{mm}^{-2}$} \\
\hline & $L A-13$ & $L A-57$ & $L A-13$ & $L A-57$ & $L A-13$ & $L A-57$ & $L A-13$ & $L A-57$ \\
\hline IV & $223.6^{\mathrm{aC}}$ & $272.4^{\mathrm{aC}}$ & $100.6^{\mathrm{aB}}$ & $97.4^{\mathrm{aB}}$ & $2.4^{\mathrm{bB}}$ & $4.9^{\mathrm{aB}}$ & $9.0^{\mathrm{bA}}$ & $16.3^{\mathrm{aA}}$ \\
\hline $\mathrm{AC}$ & $355.5^{\mathrm{aB}}$ & $363.8^{\mathrm{aB}}$ & $195.1^{\mathrm{aA}}$ & $156.9^{\mathrm{bA}}$ & $1.3^{\mathrm{aB}}$ & $1.3^{\mathrm{aC}}$ & $12.1^{\mathrm{bA}}$ & $10.6^{\mathrm{bB}}$ \\
\hline FL & $672.5^{\mathrm{aA}}$ & $582.6^{\mathrm{bA}}$ & $208.1^{\mathrm{aA}}$ & $165.6^{\mathrm{bA}}$ & $6.5^{\mathrm{bA}}$ & $8.6^{\mathrm{aA}}$ & $11.6^{\mathrm{bA}}$ & $18.9^{\mathrm{aA}}$ \\
\hline
\end{tabular}

IV: In vitro; AC: Acclimated; FL: Field; Means that are followed by the same lower case letters in rows (between genotypes) and upper case letters in columns (among environments) did not differ significantly according to Tukey's test ( $>0.05 \%$ ).

Table 6. Cuticle thickness of the adaxial (cad) and abaxial (cab) side of the LA-13 and LA-15 genotypes of Lippia alba, in acclimated and field environments.

\begin{tabular}{|c|c|c|c|c|}
\hline \multirow{2}{*}{ Environments } & \multicolumn{2}{|c|}{$\operatorname{cad}(\mu m)$} & \multicolumn{2}{|c|}{$c a b(\mu m)$} \\
\hline & $L A-13$ & $L A-57$ & $L A-13$ & $L A-57$ \\
\hline $\mathrm{AC}$ & $14.8^{\mathrm{bB}}$ & $17.2^{\mathrm{aA}}$ & $12.8^{\mathrm{aB}}$ & $11.4^{\mathrm{aB}}$ \\
\hline FL & $17.8^{\mathrm{aA}}$ & $17.3^{\mathrm{aA}}$ & $16.0^{\mathrm{aA}}$ & $16.2^{\mathrm{aA}}$ \\
\hline
\end{tabular}

AC: Acclimated; FL: Field; Means that are followed by the same lowercase letters in rows (between genotypes) and upper case letters in columns (between environments) did not differ significantly according to Tukey's test $(\mathrm{p}>0.05 \%)$. 


\section{DISCUSSION}

The results showed that immersing explants in mineral oil was effective in the in vitro conservation of $L$. alba genotypes that belong to the carvone chemotype. The effectiveness was shown for a 270-day period, and met the key conservation goals of reducing growth without affecting plant viability, reducing labor costs and maintaining the genetic material, which allows having longer time periods between subcultures or even extending them indefinitely (MOOSIKAPALA; TE-CHATO, 2010). It is noteworthy that genotypes responded differently to immersion in mineral oil for 180 days, although the responses were similar within chemotypes. Conservation of plants of the carvone chemotype (LA-13 and LA-57) in mineral oil at $18^{\circ} \mathrm{C}$ proved to be effective as measured by the three analyzed parameters. Plants of the citral chemotype (LA-29 and LA-44) had lower mean heights, but had an undesirable color (Table 2). Plants of the linalool chemotype (LA-22) had the highest values of color and height. These differences demonstrate the considerable plasticity that exists among $L$. alba genotypes.

Physically, mineral oil is an oily, colorless and chemically inert liquid, which makes it an optimal environment for conservation. Lack of oxygen under the mineral oil layer may account for the slow growth of explants because their growth is controlled by the supply of oxygen to tissues (MATHUR et al., 1991). In contrast, plant growth was not reduced in the control and water-immersed treatments because oxygen was available to the explants.

There are still few published studies in which mineral oil was used in in vitro conservation. An in vitro conservation protocol that included immersion in mineral oil was recently tested in genotypes of Bacopa monnieri (SHARMA et al., 2012), which was successful for a period of 6 to 24 months. Plants that were covered in mineral oil exhibited $80 \%$ survival compared with $66 \%$ in controls.

It is important to emphasize that plants with low color scores, i.e., plants that are greener, are preferable for in vitro conservation, even if they are somewhat taller than desired, because senescence is not desirable for conservation under a slow growth regime, and plants must be viable to resume growth when required (SANTOS et al., 2012).

Chemical analyses showed that the LA-57 genotype of $L$. alba has a higher concentration of carvone in its essential oil (77.2\%) than the LA-13 genotype $(39.6 \%)$. Carvone is an important compound because it is widely used in the pharmaceutical and perfume industries in various products, including toothpaste, antiseptic mouthwash, bread, pickles, condiments and beverages. Carvone also has antiseptic, bactericidal and antifungal activity (ANTUNES, 2005).

The leaves of the in vitro plants had reduced mesophyll and palisade and spongy parenchyma differentiation, and smaller intercellular spaces, which explains their lower values of midrib and leaf blade thickness compared with the leaves of the ex vitro plants. A similar result was found in the leaves of ex vitro Tabebuia roseo alba ('ipê-branco') plants, which had thicker leaf blades and midribs than the leaves of plants that were grown in vitro (ABBADE et al., 2009).

The leaves of plants of the carvonelimonene chemotype of $L$. alba had a simple epidermis that was coated with a relatively thick cuticle, stomata with large substomatal chambers on both sides, and mesophyll that consisted of one or two layers of palisade parenchyma and three or four layers of spongy parenchyma (SANTOS et al., 2004).

The light intensity that was used for the in vitro cultures in the present study was much lower than the light intensity of the greenhouse and field conditions. The transplanted seedlings therefore experienced greater light intensity, which caused higher photosynthetic activity. Structural changes in the leaf blade can therefore be attributed to the new environmental conditions (Fermino-Jr and Scherwinski 2009). Leaves that grow under high light intensity, including the leaves of field plants, are known to have thicker leaf blades (SCHULZE; MULLER-HOHENSTEIN 2005; DOUSSEAU et al., 2008; LAMBERS et al., 2008).

Cuticle development was significantly smaller in the leaves of plants that were grown in vitro compared with the leaves of plants that were grown ex vitro. Indeed, cuticle development in the leaves of the in vitro plants was too small to be measured. The small size might have been due to differences in light intensity and atmospheric humidity between the in vitro and ex vitro environments. Light intensity is greater for acclimated plants and even greater for field plants, and atmospheric air humidity varies with the season for acclimated and field plants (Lamhanedi et al. 2003). Cuticle thickening is ecologically related to reduction of water loss, especially in leaves that are exposed directly to sunlight. The plants show increased resistance in environments that have a water deficit because the deficit results in greater conservation of water in the plant, which prevents 
evaporation (PALLARDY; RHOADS, 1993; RISTIC; JENKS, 2002).

Glandular and tector trichomes were found on both sides of the mesophyll of all of the genotypes. Trichomes are epidermal appendages that can be found in various plant organs, including stems, flowers, roots and leaves (DICKINSON, 2000). The secretion of essential oils has been associated with the presence of trichomes in the genus Lippia (Nunes et al. 2000; Hassan et al. 2001). The availability of incident light might affect the density of glandular trichomes, which would result in an increase in the number of trichomes in plants that are grown in full sun (COSTA et al., 2010).

The tector trichomes of $L$. alba are multicellular and uniseriate. They contain two basal cells, one to three intermediate cells and one tapered cell at the end. Various functions have been attributed to these trichomes in plants, including temperature regulation, protection against herbivory, light reflection, reduction of water loss and serving as a mechanical barrier to various external factors (WAGNER et al., 2004).

No relevant anatomical variations were found within each of the chemotypes in this study.
Santos et al. (2004) examining the carvonelimonene chemotype of $L$. alba, reported a similar observation.

\section{CONCLUSIONS}

In vitro conservation of $L$. alba genotypes of the carvone chemotype by immersion in mineral oil is feasible for 270 days and is feasible for 180 days for the other chemotypes.

Leaves of the carvone chemotype that were conserved for 270 days showed plasticity that was responsive to differences in vitro and ex vitro environments.

\section{ACKNOWLEDGMENTS}

The authors thank CNPq (Conselho Nacional de Desenvolvimento Científico e Tecnológico), FAPITEC-SE (Fundação de Apoio à Pesquisa e à Inovação Tecnológica do Estado de Sergipe), CAPES (Coordenação de Aperfeiçoamento de Pessoal de Nível Superior), and FINEP (Financiadora de Estudos e Projetos) for their financial support of this work.

RESUMO: O objetivo deste estudo foi desenvolver um protocolo de conservação in vitro com óleo mineral e estudar a anatomia foliar de genótipos de $L$. alba nos ambientes in vitro e ex vitro. A conservação in vitro constou de cinco genótipos LA-13 e LA-57 (quimiotipo carvona); LA-22 (quimiotipo linalol); LA-29 e LA-44 (quimiotipo citral), três tratamentos (com óleo mineral, com água e controle) e duas temperaturas 18 e $23^{\circ} \mathrm{C}$. Aos 180 e 270 dias, avaliou-se a sobrevivência (\%), altura da parte aérea $(\mathrm{cm})$ e coloração das folhas. Os genótipos com os melhores resultados da conservação in vitro (LA-13 e LA-57) foram utilizados para estudos de anatomia. Avaliou-se espessura da nervura central, espessura do limbo foliar, cutículas adaxial e abaxial e quantidade de tricomas glandulares e tectores. A temperatura a $18^{\circ} \mathrm{C}$ foi a ideal para a conservação dos genótipos do quimiotipo carvona, com folhas verdes e baixos valores para altura, destacando-se LA-57 cuja altura não ultrapassou 2,0 cm. Aos 270 dias LA-13 e LA-57 permaneceram com folhas verdes e viáveis, com destaque para LA-57 com menores médias de altura. A anatomia do quimiotipo carvona mostrou que as plantas de campo apresentaram maiores espessuras da nervura, limbo e cutículas, e maiores quantidades de tricomas. O genótipo LA-57 obteve a maior quantidade de tricomas glandulares e tectores.

PALAVRAS-CHAVE: Verbenaceae. Crescimento Lento. Anatomia Vegetal. Morfologia.

\section{REFERENCES}

ABBADE, L. C.; PAIVA, P. D. O.; PAIVA, R.; CASTRO, E. M. CENTOFANTE, A. R.; OLIVEIRA, C. Anatomia foliar de ipê-branco (Tabebuia roseo alba (Ridl.) Sand.) - Bignoniaceae, proveniente do cultivo ex vitro e in vitro. Acta Scientiarum. Biological Sciences, Maringá, v. 31, n. 3, p. 307-311, 2009. http://dx.doi.org/10.4025/actascibiolsci.v31i3.1937

ANTUNES, O. A. C. Interfaces com a indústria. Química Nova, São Paulo, v. 28, p. S64-S75, nov./dez. 2005. http://dx.doi.org/10.1590/S0100-40422005000700013 
APÓSTOLO, N. M.; BRUTTI, C. B.; LLORENTE, B. Leaf anatomy of Cynara scolymus L. in successive micropropagação stages. In Vitro Cellular \& Developmental Biology, Largo, v. 41, n. 3, p. 307-313, 2005. http://dx.doi.org/10.1079/IVP2004606.

CAPLIN, S. M. Mineral oil overlay for conservation of plant tissue cultures. American Journal of Botany, Colombus, v. 46, n. 5, p. 324-329, may. 1959.

COSTA, L. C. B.; PINTO, J. E. B. P.; CASTRO, E. M.; ALVES, E.; ROSAL, L. F.; BERTOLUCCI, S. K.; ALVES, P. B.; EVANGELINO, T. Yield and composition of the essential oil of Ocimum selloi Benth cultivated under colored netting. Journal of Essential Oil Research, London, v. 22, n. 1, p. 34-39, dez. 2010. http://dx.doi.org/10.1080/10412905.2010.9700260

DICKINSON, W. C. Integrative Plant Anatomy. Academic Press, San Diego, 2000. 533 p.

DOUSSEAU, S.; ALVARENGA, A. A.; CASTRO, E. M.; SOARES, R. P.; EMRICH, E. B.; MELO, L. A. Anatomia foliar de Tabebuia serratifolia (vahl) nich. (bignoniaceae) propagadas in vitro, in vivo e durante a aclimatização. Ciência e Agrotecnologia, Lavras, v. 32, n. 6, p. 1694-1700, nov./dez. 2008.

http://dx.doi.org/10.1590/S1413-70542008000600002

ENGELMANN, F. Use of biotechnologies for the conservation of plant biodiversity. In Vitro Cellular \& Developmental Biology, London, v. 47, n. 1, p. 5-16, fev. 2011. http://dx.doi.org/10.1007/s11627-010-9327-2

FERMINO-JR, P. C. P.; SCHERWINSKI, J. E. P. Características anatômicas de folhas de Teca (Tectona grandis L.) desenvolvidas sob condições de cultivo in vitro e ex vitro. Evidência, Lavras, v. 9, n. 1-2, p. 17-28, jan./dez. 2009.

FERREIRA, D. F. Sisvar: a computer statistical analysis system. Ciência e Agrotecnologia, Lavras, v. 35, n. 6, p. 1039-1042, nov./dez. 2011.

GUPTA, S. K.; KHANUJA, S. P. S.; KUMAR, S. In vitro micropropagation of Lippia alba. Current Science, Bangalore, v. 81, n. 2, p. 206-210, jul. 2001.

HASSAN, M. A.; BEGUM, M.; BEGUM, S. Taxonomic significance of foliar trichomes of some species of Verbenaceae from Bangladesh. Bangladesh Journal of Botany, Dhaka, v. 30, n. 1, p. 75-78, 2001.

HENNEBELLE, T.; SAHPAZ, S.; JOSEPH, H.; BAILLEUL, F. Ethnopharmacology of Lippia alba. Journal of Ethnopharmacology, Lausana, v. 116, n. 2, p. 211-222, mar. 2008.

http://dx.doi.org/10.1016/j.jep.2007.11.044

LAMBERS, H.; CHAPIM, F.; PONS, T. L. Plant Physiological Ecology. Springer, New York, 2008. 605 p. http://dx.doi.org/10.1007/978-0-387-78341-3

LAMHANEDI, M. S.; CHAMBERLAND, H.; TREMBLAY, F. M. Epidermal transpiration, ultrastructural characteristics and net photosynthesis of white spruce somatic seedlings in response to in vitro acclimatization. Physiologia Plantarum, Copenhagen, v. 118, n. 4, p. 554-561, aug. 2003. http://dx.doi.org/10.1034/j.13993054.2003.00146.x

LEMOS, E. E. P.; FERREIRA, M. D. S.; ALENCAR, L. M. C.; NETO, C. E. R.; ALBUQUERQUE, M. M. Conservação in vitro de germoplasma de cana-de-açúcar. Pesquisa Agropecuária Brasileira, Brasília, v. 37, n 10, p. 1359-1364, oct. 2002. http://dx.doi.org/10.1590/S0100-204X2002001000002

MATHUR, J.; MUKUNTHAKUMAR, S.; GUPTA, S. N.; MATHUR, S. N. Growth and morphogenesis of plant tissue cultures under mineral-oil. Plant Science, Limerick, v. 74, n. 2, p. 249-254, dec. 1991. http://dx.doi.org/10.1016/0168-9452(91)90053-B 
MOOSIKAPALA, L.; TE-CHATO, S. Application of in vitro conservation in Vetiveria zizanioides Nash. Journal of Agricultural Technology, Hangzhou, v. 6, n. 2, p. 401-407, 2010.

MURASHIGE, T.; SKOOG, F. A revised medium for rapid growth and bioassays with tobacco tissue cultures. Physiologia Plantarum, Copenhagen, v. 15, n. 3, p. 473-479, jul. 1962. http://dx.doi.org/10.1111/j.13993054.1962.tb08052.x

NASCIMENTO-SILVA, O.; PAIVA, J. G. A. Estudos morfológicos e anatômicos em folhas adultas de Spondias tuberosa Arruda (Anacardiaceae Lindley). Boletín Latinoamericano y del Caribe de Plantas Medicinales y Aromáticas, Santiago, v. 6, n. 2, p. 36-43, mar. 2007.

NUNES, R. S.; XAVIER, H. S.; ROLIM NETO, P. J.; SANTANA, D. P.; ALBUQUERQUE, U. P. Botanical standardization of Lippia sidoides Cham. (Verbenaceae). Acta Farmacéutica Bonaerense, Buenos Aires, v. 19, n. 2, p. 115-118, 2000.

PALLARDY, S. G.; RHOADS, J. L. Morphological adaptation to drought of deciduous angiosperms. Canadian Journal of Forest Research, Ottawa, v. 23, n. 9, p. 1766-1774, 1993. http://dx.doi.org/10.1139/x93-223

RISTIC, Z.; JENKS, M. A. Leaf cuticle and water loss in maize lines differing in dehydration avoidance. Journal of Plant Physiology, v. 159, n. 6, p. 645-651, 2002. http://dx.doi.org/10.1078/0176-1617-0743

SANTOS, T. C.; ARRIGONI-BLANK, M. F.; BLANK, A. F.; MENEZES, M. M. L. A. Conservação in vitro de acessos de vetiver. Bioscience Journal, Uberlândia, v. 28, n. 6, p. 963-970, nov./dec. 2012.

SANTOS, M. R. A.; INNECCO, R.; SOARES, A. A. Caracterização anatômica das estruturas secretoras e produção de óleo essencial de Lippia alba (Mill.) N.E.Br. em função do horário de colheita nas estações seca e chuvosa. Revista Ciência Agronômica, Fortaleza, v. 35, n. 2, p. 377-383, jul./dez. 2004.

SCHULZE, D. E.; BECK, E.; MULLER-HOHENSTEIN, K. Plant Ecology. Springer, Berlin/Heidelberg, 2005. $702 \mathrm{p}$.

SHARMA, N.; SATSANGI, R.; PANDEY, R.; SINGH, R.; KAUSHIK, N.; TYAGI, R. K. In vitro conservation of Bacopa monnieri (L.) using mineral oil. Plant Cell, Tissue and Organ Culture, Dordrecht v. 111, n. 3, p. 291-301, dec. 2012. http://dx.doi.org/10.1007/s11240-012-0194-x

SOUZA, A. S.; DUARTE, F. V.; SANTOS-SEREJO, J. A.; JUNGHANS, T. G.; PAZ, O. P.; MONTARROYOS, A. V. V.; SANTOS, V. S.; MORAIS, L. S. Preservação de germoplasma vegetal, com ênfase na conservação in vitro de variedade de mandioca. EMBRAPA, Cruz das Almas, 2009. 24 p.

TAVARES, E. S.; JULIÃO, L. S.; LOPES, D.; BIZZO, H. R.; LAGE, C. L. S.; LEITÃO, S. G. Análise do óleo essencial de folhas de três quimiotipos de Lippia alba (Mill.) N.E.Br. (Verbenaceae) cultivados em condições semelhantes. Revista Brasileira de Farmacognosia, João Pessoa, v. 15, n. 1, p. 1-5, jan./mar. 2005. http://dx.doi.org/10.1590/S0102-695X2005000100002

WAGNER, G. J.; WANG, E.; SHEPHERD, R. W. New approaches for studying and exploiting an old protuberance, the plant trichome. Annals of Botany, London, v. 93. n. 1, p. 3-11, jan. 2004. http://dx.doi.org/10.1093/aob/mch011 